\title{
Recognising failure to thrive in early childhood
}

\author{
A G K Edwards, P C Halse, J M Parkin, A J R Waterston
}

\begin{abstract}
The maximum weight centile achieved by a child between 4 and 8 weeks of age was found to be a better predictor of the centile at 12 months than the birth weight centile. Children whose weight deviated two or more major centiles below this maximum weight centile for a month or more showed significant anthropometric differences during the second year of life from those who showed no such deviation. It is suggested that this leads to a logical and practical definition of failure to thrive.
\end{abstract}

The term 'failure to thrive' is applied to children who fail to gain weight adequately and therefore do not achieve a normal or expected rate of growth. It is a well known concept to child health workers. The prevalence varies, but in some communities has been reported to be as high as $5-10 \%,{ }^{1}$ and it may account for $1-5 \%$ of paediatric hospital admissions under 2 years of age. ${ }^{23}$ Failure to thrive may lead to delayed physical and intellectual development ${ }^{4}$ and it may be associated with child abuse. ${ }^{56}$ Important as the condition is, however, the disturbance of growth justifying the diagnosis is at present arbitrary. ${ }^{78}$ Growth in infancy is usually assessed by serial weight measurements alone as, unfortunately, length is rarely recorded routinely and is difficult to measure accurately. Some authors have included children whose weight is below the 10th centile in the failure to thrive group, ${ }^{9}$ and others have taken the third centile as the criterion. ${ }^{1011}$ More stringent definitions have required the child's growth trajectory to 'fall rapidly down through the centiles $^{\prime 12}$ or that weight gain should accelerate after hospitalisation. ${ }^{13-15} \mathrm{~A}$ logical and generally accepted definition of failure to thrive is needed and would enable potentially vulnerable children to be identified at an early age and facilitate both research and secondary preventative initiatives.

The term failure to thrive implies failure to achieve a normal rate of growth and so the criterion for diagnosis should involve sustained deviation for a defined period from the child's expected growth trajectory. This is the nub of the difficulty. There is at present no reliable method of estimating an infant's expected growth pattern and it may be impossible to do so precisely. ${ }^{16}$ The birth weight centile is often used for this purpose but it is determined largely by maternal influences such as height, age, parity and nutrition, smoking and alcohol consumption during pregnancy, and little by the child's genotype. ${ }^{17} 18$
The genetic contribution to a child's weight is greater by the age of $4-8$ weeks, ${ }^{19}$ by which time most children undergo a routine medical examination. Most 'catch up growth' in light for dates babies has taken place by this age, although 'catch down growth' is characteristically slower. ${ }^{19}$ For this study we therefore examined first whether the maximum weight centile between 4 and 8 weeks of age was a better predictor of the future growth trajectory than the birth weight centile. We then tested this hypothesis in a population in which failure to thrive was common.

Patients, methods, and results BIRTH WEIGHT OR WEIGHT AT 4 TO 8 WEEKS AS PREDICTOR

The weight records of two groups of singleton children aged 12-24 months from Newcastle upon Tyne and south Devon were examined. Of the 78 children in a general practice in south Devon 66 had weight measurements plotted on Sheffield charts at birth, 4-8 weeks, and 9 months, and 43 at birth, 4-8 weeks, and 12 months. 160 children attended two child health clinics in Newcastle for their surveillance. Of these 129 had weights recorded at birth, 4-8 weeks, and 9 months, and 108 at birth, 4-8 weeks, and 12 months, plotted on the GairdnerPearson charts, ${ }^{20}$ which are very similar to the Sheffield charts. ${ }^{21}$ The weight centiles at birth and at 4-8 weeks were compared with those at 9 or 12 months of age for each child. 'Deviation' between the earlier and later weights was defined as a weight that crossed two or more major centiles (third, 10th, 25th, 50th, 75th, 90th, and 97th centiles which are equidistant, each about 0.7 of a standard deviation apart from the next). Any change less than this, including a consistent growth pattern was regarded as 'agreement'. The results given in table 1 indicate that in both groups there was a trend towards the agreement between birth

Table 1 Agreement between weight centiles

\begin{tabular}{|c|c|c|c|}
\hline & $\begin{array}{l}\text { Total } \\
\text { No }\end{array}$ & $\begin{array}{l}\text { No (\%) } \\
\text { agreeing at } \\
\text { birth }\end{array}$ & $\begin{array}{l}\text { No (\%) } \\
\text { agreeing at } \\
4-8 \text { weeks } \\
\text { maximum }\end{array}$ \\
\hline $\begin{array}{l}\text { Newcastle: } \\
\text { Age } 9 \text { months } \\
\text { Age } 12 \text { months }\end{array}$ & $\begin{array}{l}129 \\
108\end{array}$ & $\begin{array}{l}98(76) \\
69(64)\end{array}$ & $\begin{array}{r}109(84) \\
82(76)\end{array}$ \\
\hline $\begin{array}{l}\text { Devon: } \\
\text { Age } 9 \text { months } \\
\text { Age } 12 \text { months }\end{array}$ & $\begin{array}{l}66 \\
43\end{array}$ & $\begin{array}{l}55(83) \\
32(74)\end{array}$ & $\begin{array}{l}56(85) \\
37(86)\end{array}$ \\
\hline $\begin{array}{l}\text { Total: } \\
\text { Age } 9 \text { months } \\
\text { Age } 12 \text { months }\end{array}$ & $\begin{array}{l}195 \\
151\end{array}$ & $\begin{array}{l}153(78) \\
101(67)\end{array}$ & $\begin{array}{l}165(85) \text { NS } \\
119(79) \text { p<0.05 }\end{array}$ \\
\hline
\end{tabular}

Correspondence to: Dr Waterston. Accepted 11 June 1990 
weight and weight at 9 or 12 months being less frequent than that between the weight centile at 4-8 weeks and later weight. This difference was significant in the combined group $(p<0.05)$.

\section{A DEFINITION OF FAILURE TO THRIVE}

These findings, combined with a period of sustained reduced growth velocity, suggest a logical definition of failure to thrive: 'A child whose weight deviates downwards across two or more major centiles from the maximum centile achieved at 4 to 8 weeks for a period of a month or more'.

In order to test the validity of this definition, a group of 63 children fulfilling it at any stage during the first two years of life were identified from the weight records of 306 children attending two child health clinics and general practitioner clinics in a deprived part of Newcastle. The poor growth of five of the 63 children with failure to thrive was attributed to organic disease. Of the remaining 58 children, with non-organic failure to thrive, 52 underwent further anthropometric assessment. Each was matched with a control of the same sex and age from the group of children with normal growth attending the same clinics. The mean age of the children at assessment was 20.8 months (range 15-27) and the mean difference in ages of the two groups of children at the time of measurement was four days. The difference between the mean birth weight and gestation of the children

Table 2 Centile differences between cases and controls

\begin{tabular}{lll}
\hline & Cases & Controls \\
\hline $\begin{array}{l}\text { Mean birth weight (g) } \\
\begin{array}{l}\text { Median birth centile } \\
\text { Median maximum centile: }\end{array}\end{array}$ & 3343 & 3355 \\
$\begin{array}{l}\text { 4-8 weeks } \\
\text { 9-12 months }\end{array}$ & $\begin{array}{l}50-75 \text { th } \\
\text { At assessment (mean } \\
\text { age 20.8 months) }\end{array}$ & 75th \\
\hline
\end{tabular}

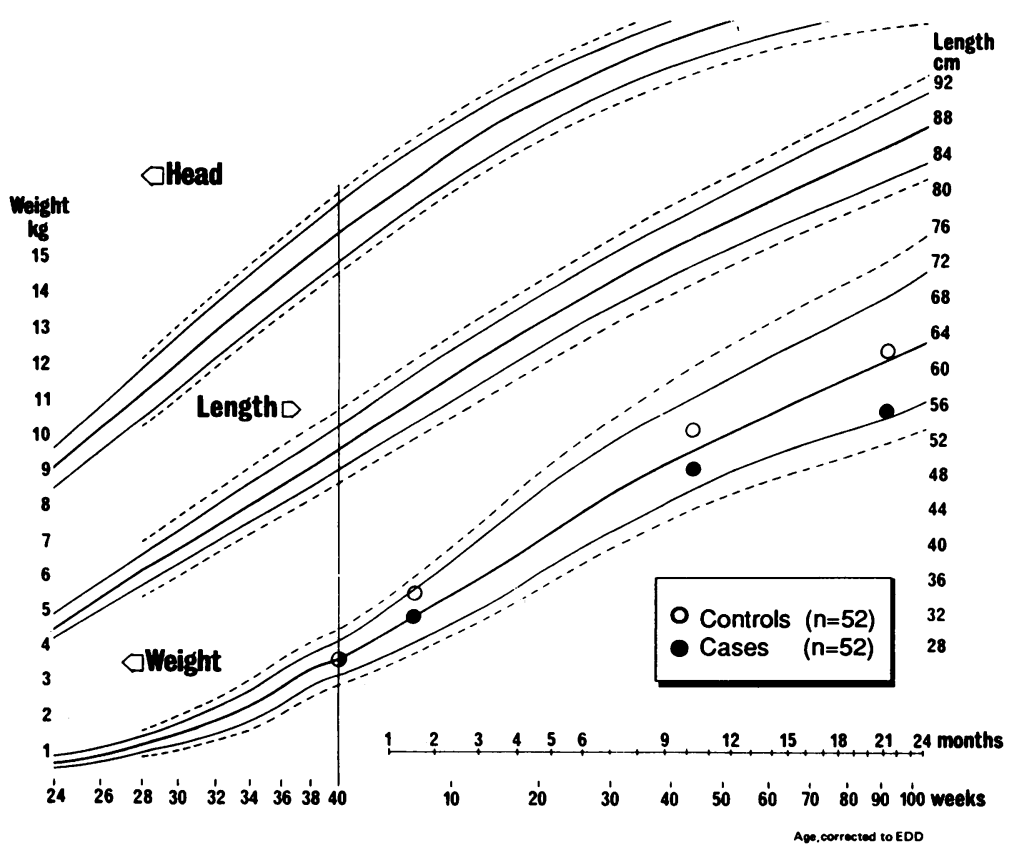

Weight centile deviations in cases and controls. who failed to thrive ( $3343 \mathrm{~g}, 39.4$ weeks) and those of the control children (3355 g, 39.6 weeks) was not significant. Those who had failed to thrive were lighter $(10 \cdot 8 \mathrm{~kg}$ compared with $12.3 \mathrm{~kg}, \mathrm{p}<0.001)$, shorter $(82 \mathrm{~cm}$ compared with $84 \mathrm{~cm}, \mathrm{p}<0.001$ ), and had smaller head circumferences $(48 \mathrm{~cm}$ compared with $49 \mathrm{~cm}, \mathrm{p}<0.01)$ than the control children. The mean body mass index of the children who had failed to thrive was less than that of the control group (16.1 compared with $17 \cdot 4, p<0.001)$. The mean age of first 'deviation' of cases from controls on the centile chart was 8.7 months (median 9 months, range 3-17). Table 2 shows the centile differences between cases and controls which are further illustrated in the figure.

\section{Discussion}

As several different definitions of failure to thrive have been used by clinicians and research workers, it is difficult to compare published studies, and in view of the importance of failure to thrive, this is clearly undesirable. We have shown that the maximum weight at 4-8 weeks provided a better estimate of the weight centile in later infancy than did birth weight in two very different groups of children. The Newcastle children were registered at clinics in the two most deprived electoral wards in the city defined from the 1981 census data, ${ }^{22}$ whereas the Devon children were from a more advantaged community. Despite this both groups showed similar patterns of infant weight gain. These findings should be confirmed by larger studies in future.

Using the suggested definition of failure to thrive, based on a sustained reduction in weight velocity, $20.9 \%$ of the Newcastle children had failed to thrive at some stage. In comparison with control children from the same environment they had significantly different anthropometric measurements, being not only by definition lighter, but also shorter and thinner. Thus although the definition produced a prevalence of failure to thrive that exceeds those reported in previous studies, it also seems to have identified a group of children who may be regarded as vulnerable and worthy of investigation and intervention from child health care workers. It demonstrates the value of regular weighing of children, a practice which, though regarded as important by parents, has been questioned by the Joint Working Party on Child Health Surveillance. ${ }^{23}$ We would suggest that a minimum level of weight monitoring in infancy should include measurement at birth, at the 6 week physical check, and at times of immunisation. These measurements would provide the means for the early detection of the effects of psychosocial deprivation as shown by growth failure.

We gratefully acknowledge the following for their support and cooperation in this study: Dr AJ Almond, Miss CC Cogswell, Mr M Murphy, Dr WR Edwards, and the Newcastle central area team of health visitors.

team of health visitors. died before publication. The other authors dedicate the work to him. 
1 Mitchell WG, Gorrell RW, Greenberg RA. Failure to thrive: a study in a primary care setting-epidemiology and followup. Pediatrics 1980;65:971-7.

2 Berwick DM. Non-organic failure to thrive. Pediatric Reviews 1980;1:265-70.

3 Sills RH. Failure to thrive: the role of clinical laboratory evaluation. Am $\mathcal{F}$ Dis Child 1978;132:967-9.

4 Dowdney L, Skuse D, Heptinstall E, Puckering C, ZurSzpiro S. Growth retardation and developmental delay amongst inner-city children. F Child Psychol Psychiatry amongst inner-city

5 Oates RK, Hufton IW. The spectrum of failure to thrive and child abuse-a follow up study. Child Abuse Negl 1977;1 119-24.

6 Taitz LS, King JM. Growth patterns in child abuse. Acta Paediatr Scand [Suppl] 1988;343:62-72.

7 Smith CA, Berenberg $W$. The concept of failure to thrive. Pediatrics 1970;46:661-3.

8 Skuse DH. Nonorganic failure to thrive: a reappraisal. Arch Dis Child 1985;60:173-8.

9 Hufton IW, Oates RK. Nonorganic failure to thrive: a long term follow-up. Pediatrics 1977;59:73-7.

10 Hannaway PJ. Failure to thrive: a study of 100 infants and children. Clin Pediair (Phila) 1970;9:96-9.

11 Shaheen E, Alexander D, Truskowsky M, et al. Failure to thrive-a retrospective profile. Clin Pediatr (Phila) 1968;7 255-61.

12 Berwick DM, Levy JC, Kleinerman R. Failure to thrive: diagnostic yield of hospitalisation. Arch Dis Child 1982;57: 347-51.

13 Rosenn DW, Loeb LS, Jura MB. Differentiation of organic from non-organic failure to thrive syndrome in infancy. Pediatrics 1980;66:698-704.

14 Ayoub C, Pfeifer D, Leichtman L. Treatment of infants with non-organic failure to thrive. Child Abuse Negl 1979;3: 937-41.

15 Ellerstein NS Ostrov BE Growth patterns in children hospitalised because of caloric-deprivation failure to thrive. Am $\mathcal{F}$ Dis Child 1985;139:164-6.

16 Whitehead RG, Paul AA, Ahmed EA. DHSS 'Present-day infant feeding practice' and its influence on infant growth In: Tanner JM, Preece MA, eds. The physiology of human growth. Cambridge: Cambridge University Press, 1989 69-79.

17 Penrose LS. Recent advances in human genetics. London Churchill Livingstone, 1961.

18 Susanne C, Hauspie R, Lepage $Y$, Vercauteren $M$. Nutrition and growth. World Rev Nutr Diet 1987;53:69-170.

19 Smith DW, Truog W, Rogers JE, et al. Shifting linear growth during infancy: illustration of genetic factors in growth
from fetal life through infancy. $\mathcal{F}$ Pediatr 1976;89:225-30.

20 Gairdner D, Pearson J. Revised Gairdner-Pearson growth charts. Arch Dis Child 1985;60:1202.

21 Keen DV, Pearse RG. Birthweight between 14 and 42 weeks gestation. Arch Dis Child 1985;60:440-6.
gen

22 Townsend P, Phillimore P, Beattie A. Inequalities in health in the Northern region-interim report 1986 . Newcastle upon Tyne: Northern Regional Health Authority and University of Bristol, 1986

23 Hall DMB, ed. Health for all children. A programme for child health surveillance. Report of the Joint Working Party on Child Health Surveillance. Oxford: Oxford University Press, 1989.

Food for the premature brain

Although it has long been suspected that early nutritional deprivation might impair later brain function, the evidence has been inconclusive. In an important paper from Cambridge, Norwich and Sheffield, Lucas et al (Lancet 1990;335:1477-81) have shown significant differences in the development at 18 months of premature babies fed a standard 'term' milk formula or an enriched 'preterm' formula containing nearly $40 \%$ more protein, $18 \%$ more energy, and extra sodium, calcium, phosphorus, copper, zinc, vitamins $D, E$ and $K$, water soluble vitamins, carnitine, and taurine.

The study was a prospective, randomised, two centre trial involving 424 babies of less than $1850 \mathrm{~g}$ birth weight and about 31 weeks average gestation. The groups seemed to be similar in all important respects apart from the feeding. When tested at 18 months' post-term the children who had received preterm formula did better as regards mental, motor, and social performance, the effect being most noticeable for motor development, for boys, and for small for dates babies. In a selected group of babies who had the highest intakes of the trial feeds, the prevalence of moderate developmental impairment (Bayley score $<86$ ) was halved in those given the preterm formula.

The study is continuing. In three other centres preterm formula is being compared with donor breast milk. Follow up into adult life is planned and the results of the seven to eight year follow up now in progress will be eagerly awaited. 